\title{
小児における肘頭ストレス骨折の一例
}

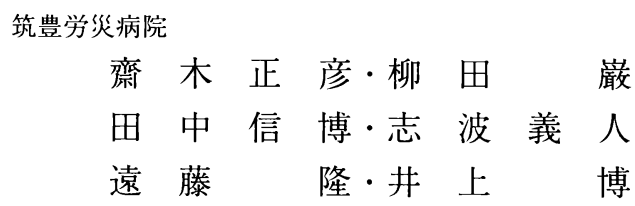

\section{A Case Report of the Stress Fracture of the Olecranon of Child}

\author{
Masahiko Saiki, Iwao Yanagida, Nobuhiro Tanaka, \\ Yoshito Shiba, Takashi Endou, and Hiroshi Inoue \\ Department of Orthopaedic Surgery, \\ Chikuhou Rousai Hospital, Fukuoka, Japan
}

\begin{abstract}
Orecranon stress fracture is comparatively rare, and it is reported as a growth period baseball elbow failure. We experienced a three year natural progress of olecranon stress fracure in a 14-year-old boy.

Thought it was difficult to differentiate whether this case was stress fracture or epiphyseal closing disorder caused by traction action of the triceps brachii musle during pitching, we diagnosed it as olecranon stress fracture due to difference in the position of the epiphyseal line of the olecranon.
\end{abstract}

Key words : olecranon stress fracture (肘頭ストレス骨折), grouwth baseball elbow failure (成長期野球肘障害), epiphyseal line（骨端線）

\section{はじめに}

肘頭ストレス骨折は，成長期野球肘傷害の一つとし ての報告が散見される．今回我々は肘頭に発生したス トレス骨折の 3 年間に及ぶ, 比較的長期の自然経過の 一例を経験したので文献的考察を加えて報告する。

症

例

（症例）14 歳, 男性

(主訴) 右肘痛

（現病歴）9歳よりソフトボールクラブに所属して いた. 平成 9 年 7 月下旬にボールを投げた後より右时 関節に疼痛を自覚した.8月に近医受診したが骨折は 指摘されず，安静のみで経過観察していた．9月より 練習再開後, 同部に疼痛自覚したため当科受診となっ た。

（局所所見）右肘伸展位にて时関節後方に疼痛を自
覚していたが, 発赤, 腫脹，圧痛は認めなかった。関 節可動域は, 伸展 $-5^{\circ}$, 屈曲 $145^{\circ}$, 前腕, 内旋 $90^{\circ}$, 外旋 $90^{\circ}$ と伸展制限を認めたが回旋制限は認めなかっ た。

（画像所見及び経過）右时単純 X 線では右尺骨时 頭部に骨折線と思われる異常陰影を認めたのに対し， 健側の肘頭骨端線は閉鎖していた（図 1)。MRIで は, 同部位に一致して $\mathrm{T} 1$ 強調像にて低信号, $\mathrm{T} 2$ 強 調像にて高信号域を認めた（図 2)。また骨シンチ （99mTc）でも尺骨頭部を中心に異常集積を認めた (図 3).以上より时頭ストレス骨折と診断して，投球 動作を中止して局所の安静のみで経過観察を行った. 3 ケ月, 6 ケ月, 1 年後の $\mathrm{X}$ 線でも, 骨癒合は得られ ていなかった（図 4). 1 年経過しても, 骨癒合が得ら れていない事から, 手術療法について本人及び家族に 説明した。しかし，ADL 上支障なく，野球（投球） 時以外は疼痛を訴えないことから，家族の同意は得ら 

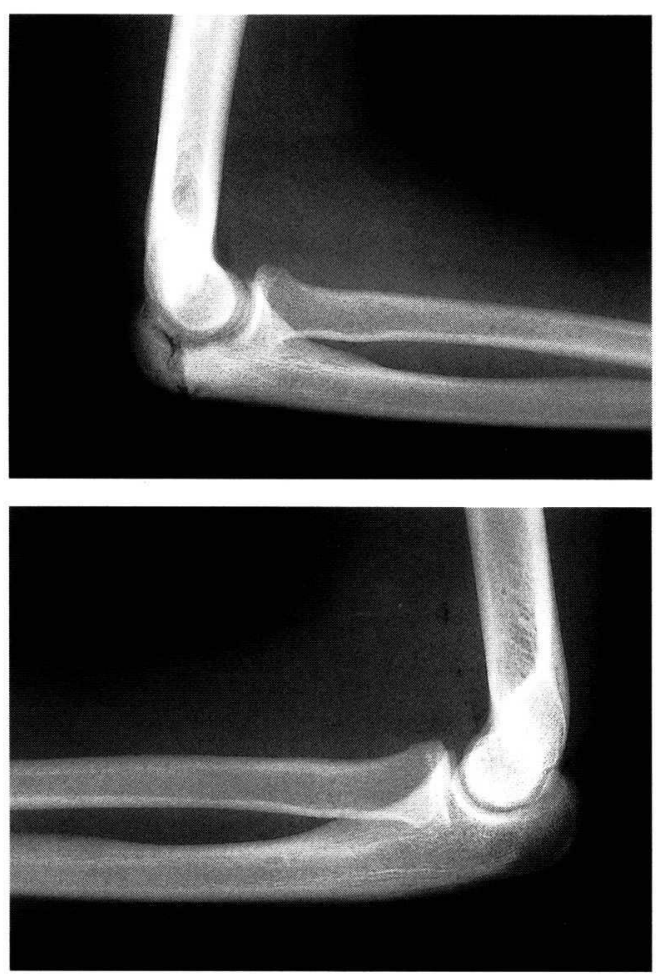

図 1 初診時単純 X 線像（上患側, 下腱側）

れなかった. 3 年後の X 線でも, 骨癒合は得られて いなかった（図 5).MRIでは，T1で低信号，T2で 低信号から高信号が混在しているが, 異常信号の範囲 は初診時に比較して狭くなっていた（図 6). 現在, 肘関節伸展 $-5^{\circ}$, 屈曲 $145^{\circ}$ と伸展制限を認めるが疼 痛なく ADLにも支障はない。

\section{考察}

野球の投球動作による肘関節障害を上腕骨内上顆の 骨端線障害に代表される tension overload to inner side of the elbow, 上腕骨の離断性骨軟骨 炎に代表される lateral compression injuries が あり少年期の投球障害としてしばしば遭遇するもので ある.一方, extension injuries として起こる肘頭 への障害は, これらに比べると少ない（肘頭疲労骨折 は疲労骨折の $1.4 \%$ に認められ, 全骨端線損傷の $0.7 \%$ を占めるにすぎない3). ). 原因として投球動作 の中で acceleration phaseの終わりから follow-
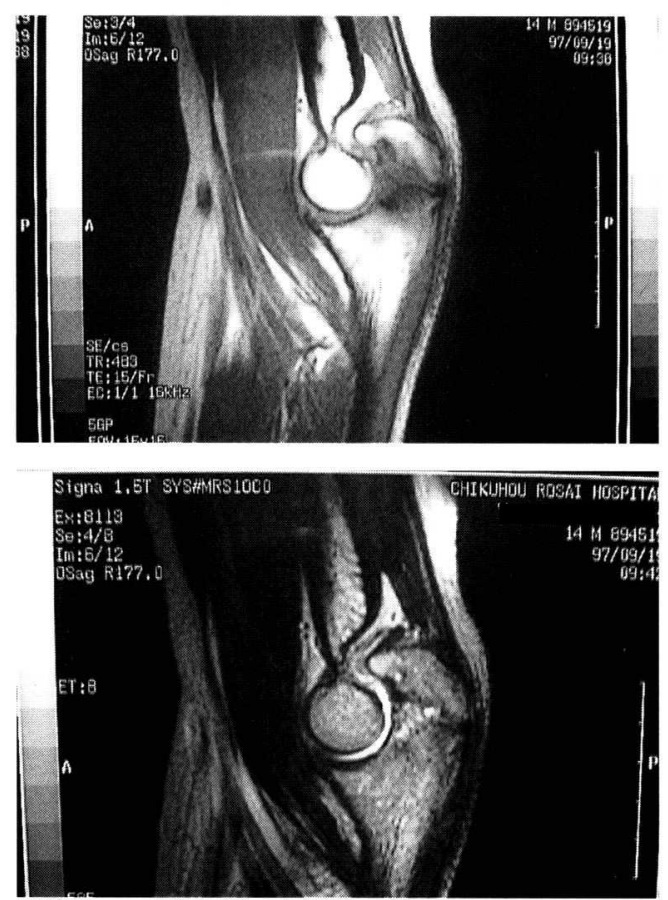

図 2 MRI像（上 T1, 下 T2） T1 低信号, T2 高信号を認める.

through phaseにおいては, 上腕三頭筋による急激 な毫引力が働き, 肘は伸展位となり, 时頭と上腕骨肘 頭窩との間に骨性の衝撃が加わる。その結果, 急性の 障害として, 上腕三頭筋の挫傷や, 三頭筋付着部の肘 頭裂離骨折がみられ, 慢性に牽引力が働くと, 肘頭の 肥大や上腕骨肘頭窩の骨棘形成が起こる. 更に, 繰り 返される制引力により，まれに肘頭の疲労骨折を起こ すことがある，と Solcum ${ }^{7)}$ は述べている.

时頭骨端核の出現は, 正常男子では通常 $9 \sim 10$ 歳 に起こり，14〜16 歳で骨端線は閉鎖するといわれて いるが, この時期に肘頭に対する頻回の強い毫引力が 加わると, 骨端線の閉鎖遅延や疲労骨折が起きると考 えられる4).

本症例は投球動作による頻回な上腕三頭筋の牽引作 用で閉鎖遅延した骨端線部，ないしは閉鎖したものの いまだ脆弱な骨端線に疲労骨折が生じたものか骨端線 閉鎖不全かの鑑別が困難であった. しかし, 时頭骨端 線の部位をみてみると本症例では骨端線の部位と明ら 

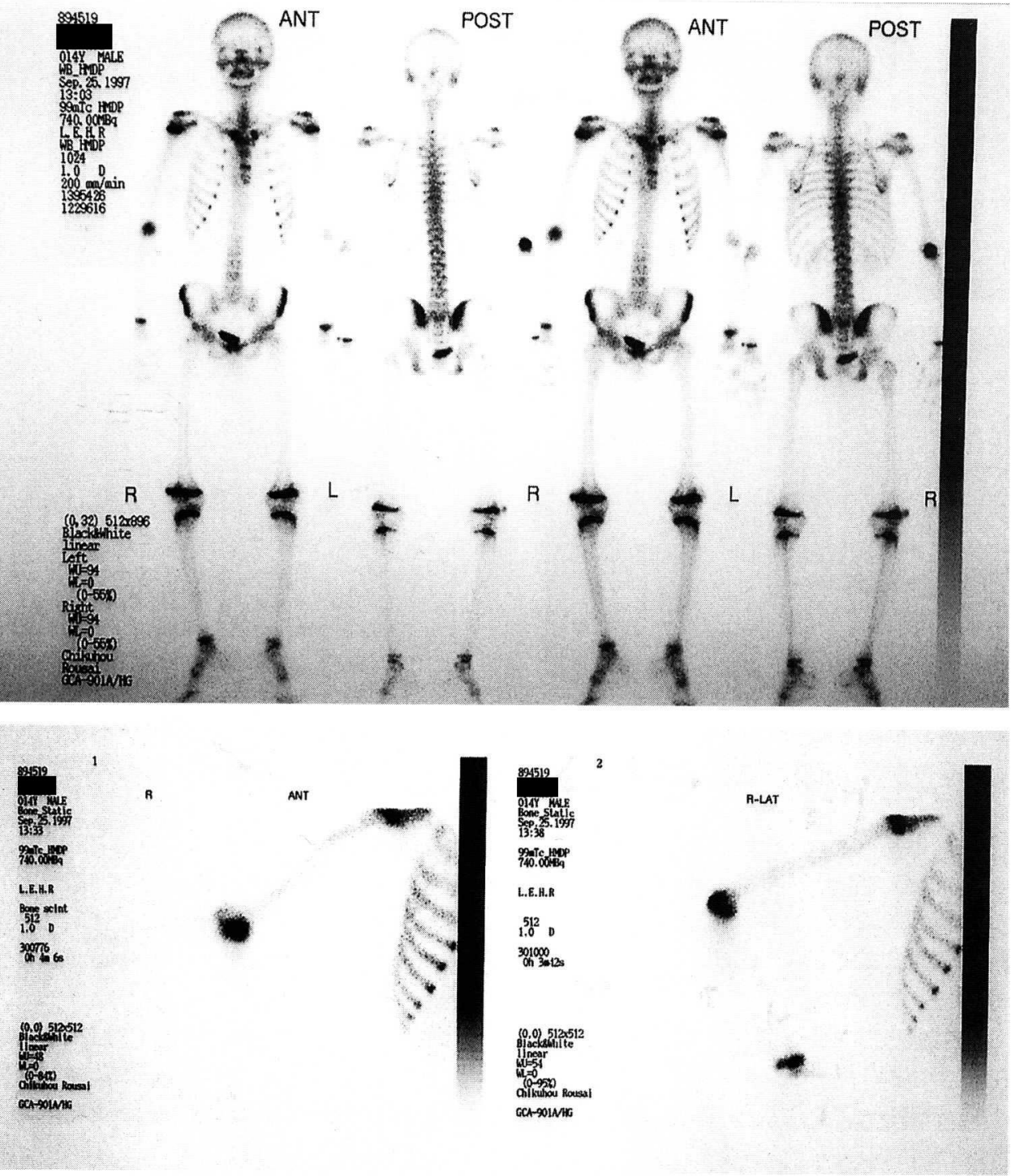

図 3 骨シンチ $(99 \mathrm{mTc})$

異常集積を認める。 

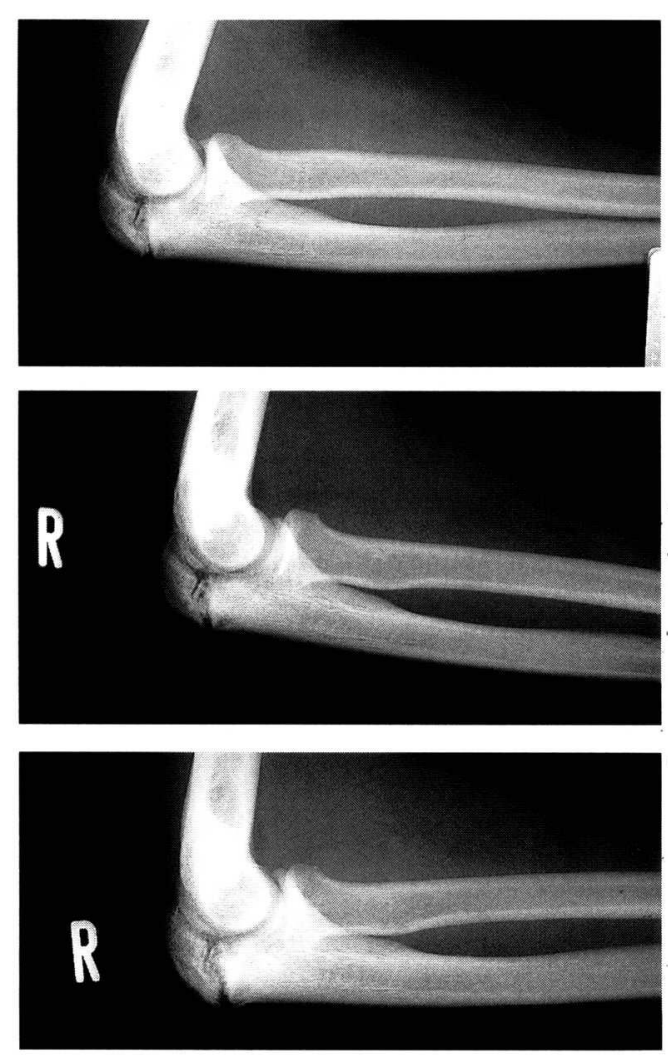

図 4 単純 $\mathrm{X}$ 線像

(上 3 ケ月後, 中 6 ケ月後, 下 1 年後)

かに異なっていた，すなわち骨端線癒合不全の場合は 时頭疲労骨折よりも近位側となる ${ }^{1}$. 従って, 本症例 は肘頭に対する頻回の杽引力による时頭疲労骨折と診 断した. また, 3 年後の MRIにおいて異常信号の範 囲が狭くなっていることから絨維性癒合の状態と考え た. 治療に関して, 保存的療法を選択するならば, 不 完全な固定による遷延治癒への進行の危険, 初診時に すでに遷延治癒段階の患者が多い, 単なる投球中止は 順守されにくい，ということから積極的に casting を行うべきであるとしている. 事実, 冨田 ${ }^{5)}$ は弓道選 手に起きた骨端離開の 2 例に対し， 5 週間のギブス固 定で治癒したと述べている. しかし, 一般的には, 転 位のある骨折や，偽関節を疑わせるものには手術療法 が推奨される. Torg ${ }^{6}$ は, 組織学的に骨折部 (时頭 骨端線部）が non-unionの状態であったことを示し, 手術療法の必要性を述べ, 更に $\mathrm{Hulkk}^{2}$ は, 成人例
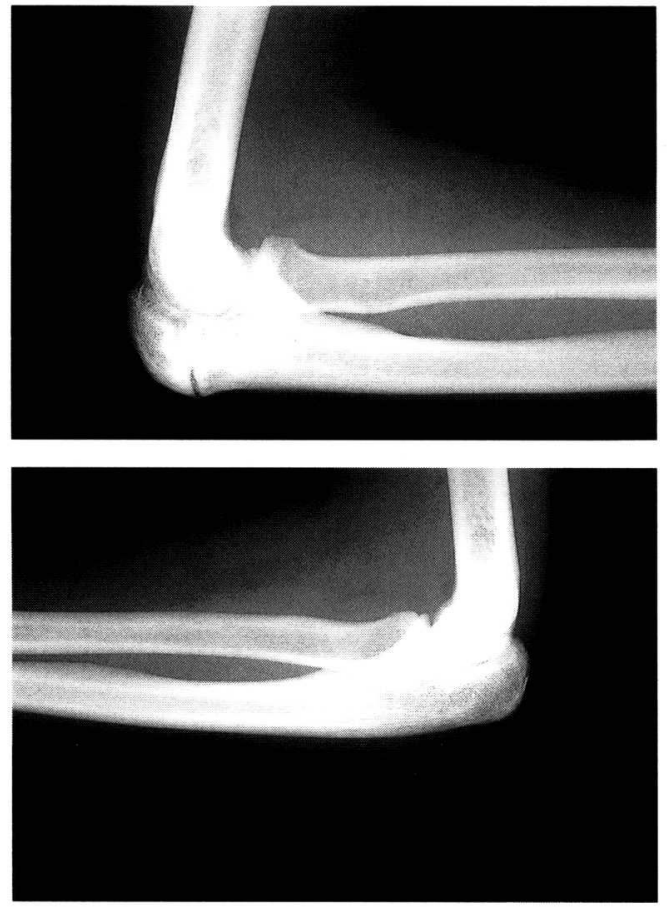

図 53 年後単純 X 線像

での術後の偽関節や，抜釘後の再骨折を経験し，初回 手術での骨移植の必要性を強調している。しかし, 初 診の時点で遷延治癒以上の段階か否かを判断すること は容易ではなく, 治療法の選択に際しては, 健常側 X 線との比較や疼痛発生時期及び, スポーツ歴などにつ いて慎重に検討し患者希望も加えて総合的に判断する ことが必要である.

今回の症例は, 長期的に経過観察したが, 発症 3 年 後の単純 X 線では肘頭部の骨癒合は得られていなかっ た.しかし, 野球を断念してから疼痛なく伸展制限は 認めるものの日常生活には支障はない. しかし, 今後, 时頭ストレス骨折の遷延治瘉例には手術療法が必要と 思われた。また, 骨端線の閉鎖していない小中学生に おいては, 過度の投球動作の肘関節に及ぼす影響は非 常に大きく，発症を予防することも重要であると考え られた。また, 適切な指導者のもとに, 投球数を制限 して練習することが大切である. 

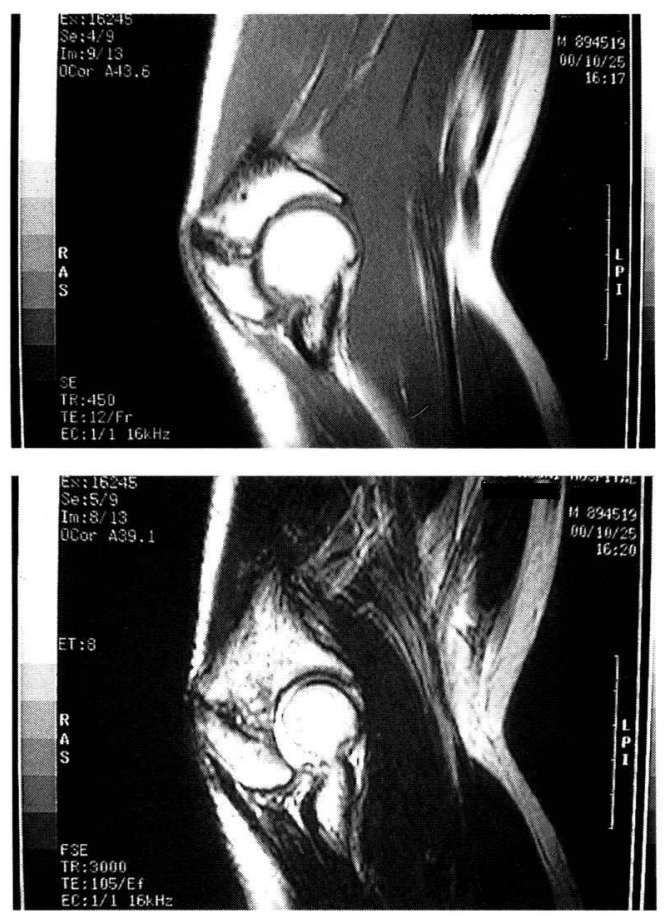

図 63 年後 MRI

T1 で低信号, T2 で低信号から高信号が混在し ている.

\section{参 考 文 献}

1) FIFTH EDITION ATLAS OF NORMAL ROENTENGEN VARIANTS THAT MAY SIMULATE DISEASE THEODORE, E, KEATS

2) Hulkko, A. et al.: Stress fractures of the olecranon in javelin throwers. Int $J$ Sport Med, $7: 210-213$, 1986.

3) Oraval, S. et al.: Non-union of a stress fracture through the olecranon epiphyseal plate observed in an adolescent baseball pitcher. J. Bone \& Joint Surg, 59-A : 264-265, 1977.

4) 高沢晴夫 : 时関節 スポーツ整形外科学 (中嶋寛之編), 南江堂, 132-157, 1987.

5）富田達也ほか：弓道によって生じた肘頭骨端離開の3 症例. 整形外科, $30: 291-294,1979$.

6) Torg, J.S. et al.: Non-union of a stress fracture through the olecranon epiphyseal plate obserbed in an adolescent baseball pitcher. J. Bone \& Joint Surg, 59-A : 264-265, 1977.

7) Slocum, D. B.: Classification of elbow Injuries from baseball pitching. Tex Med, 64 : 48-53, 1968. 